\title{
The Scholar of the Turkic World Husamuddin al-Sygnaqi and his Works Related to Arabic Linguistics
}

\author{
Kairat Kurmanbayev \\ Kairat Kurmanbayev, Ph.D Student, Faculty of Islamic Studies, Egypt University of Islamic Culture Nur Mubarak, Kazakhstan \\ Post Address: 73 al-Farabi Ave., Almaty, Republic of Kazakhstan, 050016. Egypt University of Islamic Culture Nur Mubarak \\ Email: kairatk76@mail.ru \\ Shamshadin Karim \\ Shamshadin Kerim, Doctor of Philological Sciences, Professor of Egypt University of Islamic Culture, Kazakhstan \\ Post address: 73 al-Farabi Ave., Almaty, Republic of Kazakhstan, 050016. Egypt University of Islamic Culture Nur Mubarak \\ Email: nurmubarak2013@mail.ru
}

\begin{abstract}
Alau Adilbayev
Alau Adilbayev, Ph.D. Teacher of Egypt University of Islamic Culture, Kazakhstan, Post address: 73 al-Farabi Ave Almaty, Republic of Kazakhstan, 050016. Egypt University of Islamic Culture Nur Mubarak; Email: uijumisi@mail.ru
\end{abstract}

Doi:10.5901/mjss.2015.v6n5s2p174

\begin{abstract}
It is a known fact that along with Arabs other nations also contributed considerably to the development of Islamic civilization. Enormous contribution was made by Turkic nations to sciences as Islamic study, natural science. In this article we will dwell upon life and works of legal scholar, theologist and linguist Husamuddin al-Sygnaqi who was born in Kazakh land and Arabic linguistics matters which are mentioned in his works. Husamuddin al-Sygnaqi was also recognized as a prominent linguist by deeply immersing in linguistic matters in his works devoted to Islamic studies and linguistics. In the article the studies have been done to his books called "Al-Najah at-tali tilua al-marah", "Al-Muassal fi sharh al-Mufassal", also, linguistic matters in his works have been analyzed.
\end{abstract}

Keywords: Linguistics, Arabic language, tafsir (interpretation), hadith, fiqh

\section{Introduction}

Renovation of our ancestors' heritage is required for re-evaluating our national identity and determining its significance in modern world. Preserving and handing over our religion and culture to generations to come is becoming the pressing issue on the agenda. Developing our spirituality, broadening our knowledge has caused us to give a closer look at ancestors' heritage. There has arisen the necessity to scrutinize Islamic values and knowledge in it from scientifictheoretical perspective. As a result of the works executed in this regard, we have access to spiritual heritage of scholars who came from the Turkic world, particularly from Kazakh land. Among them life and research works of Imam Husamuddin al-Sygnaqi who made a huge contribution to Islamic theology and law have been defined. The fact that the scholar's works and data about him had been written in Arabic, that they had been scattered over in the form of manuscript in libraries of the world and that their content was mostly religious, inhibited recognition of the scholar in Kazakhstan for a long time. Nonetheless, the scholar was presented in Kazakh language for the first time by such national scholars as professor A.Derbisali, professor Sh.Kerim. At the present it is known that al-Sygnaqi's manuscripts were preserved in Turkey, Egypt, Saudi Arabia, Uzbekistan, Germany, India, etc., and some of his manuscripts and copies have been brought to our country.

In the Middle Ages Muslim scholars paid attention not only to studying religion, but also Arabic language, because whatever science of Islam we take as example, their basis, theory and methodology, terms and concepts are based on Arabic language. Concluding a verdict out of any religious text and resolving issues of legal content in it, first of all, requires comprehension of the text. We can achieve it only by scrutinizing its linguistic structure and narration method.

Husamuddin al-Sygnaqi also dedicated three works to linguistics, made himself known as an expert in linguistics 
by discussing linguistic matters in some of his works written in the domain of Islamic studies.

\section{Husamuddin al-Sygnaqi and his Spiritual Heritage}

\subsection{Husamuddin al-Sygnaqi's life}

Valuable information concerning al-Sygnaqi can be found in autobiographic books (tarajum, tabaqat) written in the middle ages by Hanafi scholars. Although in the mentioned works there is new information about his mentors, followers, his surroundings, works, the fact that certain data are repeated and are delivered in brief form makes it complicated to sufficiently study the scholar's life.

The scholar's name "al-Sygnaqi" was assigned to him as he had been born in the ancient city Syganaq which was in Kazakhstan, Qyzylorda oblast, Janaqorgan region. Al-Zabidi mentioned this city as Sugnaq in his work and stated it was one of areas of Buhara city (Al-Zabidi 1989, 25/450-451). The only difference is harakats which are put over letters. That phonetic peculiarity might have been made by those who had edited and republished the book. In the book called "Buldan al-hilafa ash-sharqiya" Ali Yazdi states: "In old encyclopaedias about settlement places there is no evidence about this city. However Sygnaq is the main city of Qypshaqs, it is located twenty four farsahs away from the north of Otyrar city" (Guy Le Strange 1985, 529).

The archeologists K.A.Aqyshev and K.M.Baypakov gave the evaluation of this city as being the second famous city after Otyrar among medieval cities (Kerim 2012, 61).

Bartold in his work called "Turkistan" states: "Syganaq is a capital of non-Muslim Qypshaqs. It is located twenty four farsahs away from Otyrar city. At the present there are remainders of cities as "Sunaq qorgan" or "Sunaq ata"' (Barthold 1928: 179).

One of the reasons the city was renowned is that in its 2000-year history it had been the capital of Qangly tribe, Qypshaq Handom (kingdom) (XI -XII c.), Aq Orda (XIII - XIV), Abilhayr Handom (XV century), Qazaq Handom (XVI c.). Regardless of numerous attacks the city suffered, it would continuously revive as the city was situated along the Silk Way, between Central Asia and Deshti Qypshaq Handom.

This city was the motherland of prominent people who made a huge contribtion to the development of Islamic studies and left invaluable heritage behind like Husamuddin al-Husein ibn Ali ibn Hajjaj ibn Ali al-Sygnaqi. Al-Sygnaqi, first of all, was recognized as the salient Islamic expert of his time, prominent representative of Hanafi school and renowned figh expert. Apart from that he was a theologian, linguist who funneled his efforts and works into Islamic theology, wrote about matters of Arabic linguistics. He lived most of his life in the second half of XIII century, the last 1015 years of his life passed in the first half of XIV century.

XIII century was recorded as the era when Muslims' fate was at stake, full of historical events which left indelible imprints for Islamic community. At that period Mongols who had scorched the turfs of Syganaq, Horezm and Buhara reached Middle and Near East nations. As a consequence, in the second half of XIII century the Abbasi Caliphate that had ruled for the whole five centuries fell. It was time when Hulagu Han, the leader of Mongol occupants who had never recognized any religion conquered the center of Islamic world Bagdad city. The unending battles between Egyptians and cross-bearers were going on. The spiritual life activities decreased at those times due to continuous wars. However, due to great victories achieved by Muslims towards the end of that century spiritual life revived, during the reign of Sultan Beibars over Mamluks science started developing again, many schools and libraries were erected. The centers of science like Egypt, Sham started thriving again. It is conspicuous that at that time and in following centuries, contribution of scholars from Turkic world to enriching Islamic culture was enormous (Kerim 2012: 12).

\subsection{Scientific investigations and creative works}

He who had been born in Syganaq city along Syr river set off a long journey to the beacons of science in the East of Islamic world in his early youth in search of knowledge. He stayed much time in Buhara which was one of the largest scientific centers of that time, meeting prominent scholars there and gaining knowledge from them.

What we can discover from the preface of his manuscript "Al-Nihaya" is that Hafizuddin listened to the book "AlHidaya" from al-Buhari in the madrasah and mosque al-Badriyat in the city of Mariy (modern Turkmenistan) and heard it from Fahruddin al-Maimargi in the madrasah "Al-Muqtadi" in Buhara.

Then he himself taught his knowledge to others, perfected his skills and became a scholar. We can clearly realize the level of his knowledge from his works written in several fields, from the fact that he was educated by scholars and trained followers and his recognition by scholars as well as from his research works in Islamic studies, linguistics. 
Particularly, his works in Islamic law, basics of Islamic law and Islamic theology and Arabic linguistics make us realize how deep his knowledge in those domains are. His large ten-volume commentary book "Al-Nihaya" to the well-known figh book of Hanafites also demonstrates that he dad risen to the peak of knowledge and towered over his fellow people.

Having focused on Arabic linguistics, he read the book "Al-Mufassal" by Hafizuddin al-Buhariden al-Zamahshari (Suyuti 1979: 1/537).

In his book "Al-Uafi" which is an interpretation of the book "Al-Muntahab" of imam al-Ahsikasi he mentioned that he had finished that work in 692/1293 by Hijrah in the mosque and tombstone of al-Ahsikasi (Al-Sygnaqi 2003: 5|1983). It is known that the author of "al-Muntahab" al-Ahsikasi was buried in the cemetery in Kalazabad city where seven judges were six feet under. Husamuddin afterwards headed off to Horezm city, during his journey that is in 693/1294 he stopped by al-Abbasiya hanaqah (place of worship of sufis) in Kas city (Al-Sygnaqi 2003: 1|53). There he met the author of the book "Al-Muqtabas" al-Fahru al-Asfandari and gave him the right to teach (ijaza). After that he returned to Horezm and rewrote his book "Al-Uafi". It was the end of the year 693/1294. In the manuscript preserved in Paris National Museum he writes that he finished it on Monday $24^{\text {th }}$ zulhijja of 693. Amir Katib al-Itqani learned the "Usul" of Fahr al-Islam al-Bazdaui from him (Itkani 1999: 20). Then he moved to Iraq, there in Baghdad in Abu-Hanifa mashhad (bruied place) he taught, drew fatwas and wrote research works. During that journey, particularly, in the year of 700 by Hihrah at the end of the month Rabii al-Auual he put finishing lines to his work "Al-Nihaya". After, he departed from Baghdad to perform Hajj and stopped in Sham. In the year of 704/1304 by Hijrah on Friday on the eighteenth of the month of al-ula he finished his work "Al-Kafi" in Halab city, in 710/1310 he was in Damascus. Afterwards he travelled to Egypt and from there he would go on hajj travel (Salami 2000: 41). After hajj he had returned to Sham, in 711/1311 at the beginning of the month of rajab in Halab city he met the chief judge (judge of judges) Nasruddin ibn al-Adim. Having rewritten a copy of his "Al-Nihaya" from the beginning till the end for him, he granted the right to deliver and teach his works and interpretations, everything uttered by him to others (Lakhnawi 1998: 107). The scholars like Ismail Pasha al-Baghdadi said that Husamuddin asSyganaqi had passed away that year which is 711/1311 in Halab (Bagdadi 1951: 1/314), Haji Khalifa refers to 710/1310 (Haji Halifa 2008: 3|333), some researchers said he had died in 714l1314. According to data given by Muhammed ibn Rafig as-Salami and other scholars, his days had come to the end on the way to his motherland and was buried in Mariy city (Salami 2000: 41). Mariy is believed to be a city in modern Turkmenistan. "Islamic Encyclopedia" that was published in Turkey also cites that he died in 714l1314 (Rahmi Yaran 2009: 37|164).

Information about the life of the scholar is deficient, just as there is no exact clue of the date of his birth, there are discrepancies in scholars' data about the date of his death as well.

\subsection{His works}

Husamuddin al-Sygnaqi wrote works on Islamic law, basics of Islamic law and Islamic theology and Arabic linguistics. Mostly he was recognized for writing interpretation to books that were widespread in his times of Hanafite scholars who had lived before him. The reason was that in that period the most widespread method in Muslims science was explanation and interpretation. However as-Syganaqi did not confine himself with interpretation. He also had treatise manuscript of his own production.

The interpretation work "Al-Nihaya" to the well-known book of Hanafites in Central Asia in Islamic law field was created by him. The copy of the book which is preserved in "Darul-Kutub" of Cairo was made and brought to Kazakhstan, it is exhibited now in regional study museum in Zhanaqorgan town of Kyzylorda oblast.

Likewise, the scholar devoted investigation to Islamic law and left behind two valuable works. They are:

- "Al-Uafi fi usul al-figh". He gave a thorough explanation to "Al-Muntahab fi usul al-mazhab" ("Selected compilation about basics of mazhab") spread widely as a textbook in the days of al-Ahsikasi (died in 1247).

- "Al-Kafi sharh al-Bazdaui" ("Full interpretation to al-Bazdaui"). In this research work the scholar gave a close investigation into and interpretation to the book called "Kanzu al-usul ila ma'rifat al-usul" ("Treasury of knowing figh basics") of Fahr al-Islam al-Bazdaui (1010-1089).

Another field in which the scholar put pen to paper is Islamic theology. He wrote his work called "Al-Tasdid fi sharhi al-tamhid li kauagid al-tauhid" after conducting investigations on the basis of theological principles and rules established in the Central Asia. That is the interpretation done to the work of the author of several books in Kalam field, renowned figh expert of Mauarannahr area, Imam Abu al-Mugin Maimun ibn Muhammed an-Nasafi. This work dedicated to Islamic theology has become the cornerstone of the master degree dissertation at Ummu al-Qurra University in Mekka. The author of "al-Jauahir al-Mudia" Abu al-Ufa al-Qurashi mentioned in his book that the above-mentioned book of al-Sygnaqi was a huge one-volume book and he had the original copy of it (Qurashi 2005: 140). Most of Husamuddin as-Syganaqi's works have been preserved as manuscripts, but some of them haven't reached to our days. 


\section{Husamuddin al-Sygnaqi's Works Related to Arabic Linguistics}

Husamuddin al-Sygnaqi apart from being the expert of religion who wrote invaluable pieces in Islamic theology and law was also a linguist who had driven pen in Arabic linguistics. As evidence we can mention the scholar's works. To us are known three works on linguistics. They include:

1. "Al-Muassal fi sharh al-Mufassal" is the interpretation work made to the book of Az-Zamahshari on Arabic grammar. It is deemed to be his third work after al-Uafi and "an-Nihaya".

2. "Al-Najah at-tali tilua al-marah" is a book on Arabic morphology.

3. "Kitabu al-Muhtasar". It is the small work on morphology. There were not given data about that book in the sources. Only from the preface of the above-mentioned "Al-Najah" of al-Sygnaqi do we know that he had such a book. However it is not definite if this book of the scholar was preserved or not. The manuscripts of the previous two were preserved. Those two works of his have been the matter of special investigation lately and has been defended as $\mathrm{PhD}$ and master degree dissertation work at Ummu al-Qura University, Arabic language faculty in Mecca. The first is the PhD dissertation work of Ahmad Hasan Ahmad Nasr about "AlMuassal fi sharh al-mufassal" defended in 1998, the second is the master degree thesis of Abdullah Osman Abdurrahman Sultan about "Al-Najah" written in academic year of 1993-1994.

\subsection{His book called "Al-Muassal fi sharh al-Mufassal"}

Ahmad Hasan Ahmad Nasr in his dissertation work gave a description to two manuscript versions of "al-Muassal", according to him both two versions have been preserved in Turkey, the first preserved in Salim aga library by the number 1167. It is now stored in Suleymania library, Ali pasha department with that number, the second has been kept at Shahid Ali library in Turkey with the number 2484 (Ahmad Nasr 1998: 65). We have encountered the preserved copy at Hafiz Asad library in Arabic Republic of Syria with the number 640/. Likewise, the Doctor Abdurrahman ibn Suleyman alUsaymin who had researched the book "Al-Tahmir" of Al-Horezmi stated: "K.Brokelman writes wrongly that the manuscript kept in "Salim aga" library in Turkey with the number 1167 belonged to Alamuddin an-Andalusi (passed away in 661 by Hijra). The reason of his mistake was that in "Kashfu al-Zunun" it was mentioned al-Andalusi had an interpretation work "Al-Muassal'"'. (Usaimyin 1990: 1|53). That book of Al-Sygnaqi was mentioned in such biographic books like "Kashfu al-Zunun", "Raudatu al-Jannat", "Hadiatu al-Arifin", "Al-Aglam" and "Mugjmau al-Muallifin".

Haji Khalifa mentioned Husamuddin Huseyn ibn Ali al-Sygnaqi among those who had made interpretation to "AlMufassal" and clarified his work was called "al-muassal" and that it was compiled from "Al-lqlid" and "Al-Muqtabas" (Haji Khalifa 2008: 3|333). Al-Sygnaqi met both mentioned authors. From resources it is known that after he had finished his book "Al-Uafi" in 693 (1294) in the city of Kas in Abbasi hanaqah (worshipping place of sufists) he met the author of the book called "Al-Muqtabas" Fahruddin al-Asfandari and gave him the right (ijaza) to teach his preaches and book to others upon his request (Al-Sygnaqi 1993-1994: 42-42).

That he had met the author of "Al-Iqlid" al-Jandi in Horezm was narrated in the preface of his interpretation work.

The scholar explained the reason of his writing that work in the preface as: "after terminating "an-Nihaya fi sharh alhidaya" and taking some rest I wanted to take up another science which would be beneficial as well as useful to people. Moreover, I wished to gain benefit and knowledge from non-depletable wealth this science wields. Thus, having noticed usefulness of "Al-Mufassal", a solid structure in its text and content I chose this work. There is a saying regarding it which goes as "There is no use of other great ideas when one has this book in hand"' (Al-Sygnaqi 1998: 1-2). It is not a coincidence that al-Sygnaqi who earlier had perfected his knowledge by interpreting two fundamental works in the domain of fiqh and usul al-fiqh, apart from sharia started investigating the separate subject as grammar, the extremely hard matters of theory of Arabic language, because comprehending hidden meanings in Quranic and hadith verses, conceiving obscure shara'i texts would require mastering the language at the highest level.

Abu al-Qasym ibn Omar al-Zamahsharu (1075-1143) was assigned nicknames "Ustazu al-arab ua al-ajam" (teacher of Arabs and non-Arabs), "Fahru Haurazm" (Honour of Horezm) even in his healthy days. His "Al-Mufassal fi san'ati al-igrab" (detailed analysis of formation of inflexion) - his famous book written in 1119 - 1121 which gives deep insight to Arabic grammar. It was widely used in the age of Ayubis in Egypt and Sham, the King assigned one thousand dinar and other rewards to those who learned it by heart (Al-Khwarizmi 1990: 43). The investigators of following ages wrote many explanatory works to that book. According to K.Brokelman's data there were more than 30 works written as interpretation of "Al-Mufassal". Abdurrahman ibn Suleyman al-Usaymin, the doctor who researched the book of alHorezmi called "Al-Tahmir" enumerated 94 interpretation works dedicated to "Al-Mufassal" (Usaimyin 1990: 47-59). "AlMuassal" of al-Sygnaqi is one of those works. He is believed to have started it in 700 s, because in the introduction of the 
interpretation it was mentioned that he had read the book "Al-Mufassal" of al-Zamahsari to his teacher Hafizuddin alBuhari in 676/1277. This was confirmed by imam Suyuti in in his work "Bagiatu al-Uagat" (Suyuti 1979: 1/537).

This work of al-Sygnaqi is characterized by quotations from poems, scientific materials full of verdicts and examples. He, first of all, referred to Quran, books of commentaries and hadith compilations. In linguistics he referred to dictionaries of his fellow countryman, famous linguist from Farab Ismayl al-Jauhari as "Taju al-Luga", "Sihah al-Arabiya". Furthermore, it shall be noted that the scholar took plenty of information from the dictionary of Ahmad ibn al-Faris "Mujmalu al-Luga", the book of al-Mutarrazi called "Al-Mugrib fi tartibi al-Mugrab" which gives commentaries to statements made by Hanafi legal experts (faqih). The well-known work in oratory "Nihayatu al-igjaz fi dirayati al-igjaz" of Fahruddin al-Razi, from belles-lettres al-maqamat of Hariri, "Diuani" of Abu Mansur al-Katib were used as reference. He also took for basis books on linguistics and grammar of such authors as: Sibauihi, Zamahshari, Ibn Hajib, al-Horezmi, alNasafi, Ibn Malik and al-Asfandari". Sometimes he referred to his own books like "Al-Kafi".

Al-Sygnaqi having analyzed interpretations done to "Al-Mufassal" before him, utilized their practice for his purpose. Especially, quite considerable impact did works of scholars from Central Aisa, Mauarannahr as al-Asfandari, al-Horezmi, al-Jendi make.

Some of the sharh works (interpretation) done to "Al-Mufassal" are large, some of them are concise. According to al-Sygnaqi his book "Al-Muassal" was based on "Al-Iqlid" of al-Jendi and "Al-Muqtabas" of al-Asfandari, he said he had extracted the most important pieces of both, taken what one is deficient for from the other. He explained the reason by saying: as "Al-Iqlid" is the big-sized interpretation which tackles the most complicated points of the book, explains verses and is capable of answering emerging questions, l've used this book. Nonetheless, some necessary explanations, all lines of poems and authors as well as answers to certain unclear questions are not presented as neatly as in the book "Al-Muqtabas". However augmented commentaries to meanings of poem lines given in the book "al-lqlid" cannot be found in "al-Muqtabas". I have complemented what is missing in one book with commentaries presented in the other when writing this book. Thus, I have gathered the advantages of two interpretations in explaining the main text" (AlSygnaqi 1998: 4-5).

Although al-Jendi agreed with al-Zamahshari on some issues, disagreed with him on some matters and enunciated his arguments broadly. Such a principle is often observed in the works of Husamuddin. The number of examples taken from Quran, hadiths, statements of sahabs and tabiins, poems and speeches of Arabs is almost equal.

When making a review to interpretation works of Al-Asfandari, al-Horezmi and al-Sygnaqi we can contemplate some peculiarities and similarities between them. For instance, similarities can be noticed in evidences and references they used. However from the perspective of scientific materials there is a blatant difference between Al-Sygnaqi and alHorezmi with al-Asfandari. Al-Sygnaqi did not analyze the whole book, but selectively studied some words in the book and intended to dwell upon them by unfolding their meaning, while al-Horezmi and al-Asfandari made a complete interpretation of the book. "Al-Muqtabas" of al-Asfandari is characterized by diverse scientific base, while "Al-Tahmir" of al-Horezmi cannot be considered so large-scale.

Al-Sygnaqi took principles and theoretical hypotheses of Basra's scientists for basis in his ideas and grammatical conclusions. The ideas and works of scholars from Basra was a source of inspiration. That can be utterly seen from the way he referred to knowledge of members of that school, supported their visions and put forth ideas of Basra school when discrepancies occurred. There are many examples that can serve as evidence to that.

Husamuddin al-Sygnaqi did not introduce a new, innovative method in grammar, because before him the basics of Arabic grammar and domains had been etsblished in full, all grammatical rules and principles had been created, scrutinized and analyzed. On the scholars of the following generations was laid the task to study, complement, systematize that heritage and classify it. Therefore the scholars of following ages did not introduce any innovations in grammar, they just provided the connection between old ideas and new ones. In this direction al-Sygnaqi demonstrated diligence and determination. In his work "Al-Muassal" he selected grammatical materials skillfully, weighed and brought them to harmony and fulfilled his goals in full. He dwelled upon some ideas of scholars who had founded grammar, put forth those which he liked, accepted conclusions he thought were applicable and projected his critical opinions to those with which he did not agreed.

The weak point of al-Sygnaqi's "Al-Muassal" is that even though he covered the whole text, he gave explanation only to some parts of it without paying attention to the rest and reiterated remarks of al-Zamahshari concerning some matters with no change. Likewise, there are many unchanged texts conveyed from al-Horezmi. The fact that he quoted them unchanged without criticism must have hinted his solidarity with them. However we can notice some examples of alHorezmi denied by him in some places.

He showed his solidarity with some viewpoints or syntactical matters in al-Horezmi's "Al-Mufassal", but wrote reasoning and criticisms to some of them. 
Table 2. Classification according to majority of scholars

\begin{tabular}{|c|c|c|c|}
\hline \multirow{6}{*}{ Majority of linguists } & Regular & \multicolumn{2}{|l|}{ Irregular } \\
\hline & 1. Sound & \multicolumn{2}{|l|}{ 1. Assimilated } \\
\hline & 2. Doubled & \multicolumn{2}{|l|}{ 2. Hollow } \\
\hline & 3. Hamzated & \multicolumn{2}{|l|}{ 3. Deficient } \\
\hline & & \multirow{2}{*}{ 4. Highly deficient } & a) Dispersed aggregation \\
\hline & & & b) Contiguous aggregation \\
\hline
\end{tabular}

In Arabic morphology the letters «او 《" «" the beginning, in the middle or at the end the verbs are described differently. Verbs coming at the beginning with one of weak letters are called "assimilated verb", if the middle letter is weak, it is called "hollow verb", if the last letter is weak, it is called "deficient verb". The linguists unanimously agreed that verbs free of weak letters are "regular verbs". Most linguists included "mudagaf" (duplicated) and "hamzated" verbs in them while we can see that al-Sygnaqi labeled them as weak verbs.

In each chapter morphological matters like positions of weak letters in the verb and condition during tense conjugation, change of one letter into another, letters being dropped for certain reasons were comprehensively expounded. Also, there were shown cases when changes were needed or not needed as well as formation patterns. He dwelled upon nominations only in cases when they were important.

The backbone of the first part which accounted for one third of the book was "regular verbs". In order for the verb to be regular, its first letter «ف», middle «ع», last «ل) letter need to be free of weak letters and Hamza and duplicated letters. Other than that, in that chapter the verbs coming in past, present tenses and in imperative mood, reasons of their changing or unchanging grammatically were enunciated by scientific reasoning and hypotheses of scholars.

He gave a special mention to similarity of the verb in present tense with "ismu al-fa'il" (nominative word) and ways of its formation as well as ways of its coming with letters "noon an-niswa (feminine noon)", "noon at-takid" (noon of emphasis). Particularly, the reasons why verbs in present tense start with one of letters 《l», 《ن,, 《"», 《ت were identified (imperfect vebs), it was stated that (af'alu hamsa) «five verbs» were exposed to grammatical changes when they come with letters «أl», «و», «ي».

Likewise, in this chapter it was told about imperative mood being derived from present tense and the reason why the letter "Hamza" precedes the verb when the second letter of the verb in present tense is with "sukoon". Having confirmed that verbs in imperative mood do not change, differences in conclusions of scholars from Basra and Kufa were brought to attention. described.

In the chapter ways of formation of "fa'il" from three or four-letter verbs and "maf'ul" and ways of its formation were

In the second chapter dedicated to Mudagaf (duplicated) verbs duplication, assimilation and principles of changing were covered. Al-Sygnaqi included mudagaf (duplicated) verbs in irregular verbs due to the fact that one of the duplicated

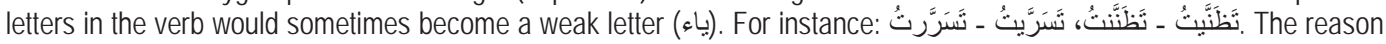
of its being mentioned before verbs "mahmuz", "mugtal" might have lain in its closeness to "regular verbs". Al-Sygnaqi divided duplicated verbs into several forms and wrote about ways of assimilation of sounds in them. The main reason was that the identical letters repeated. The author declared the following statements regarding cases when the identical letters repeat in the duplicated verbs:

1. when the identical letters repeat and in case the first letter is sukooned while the second is with harakat, it is mandatory that sounds get assimilated.

2. the assimilation is forbidden when the identical letters repeat, the first letter is with harakat and the second is sukooned.

3. When both letters are with harakat:

a) if it takes place in one word, assimilation is compulsory.

b) if they come in two separate words, assimilation is allowed.

c) Cases when they come in word, but duplication is impossible. For example: the word ${ }^{2}$. Likewise, he considered some cases when repeating of identical letters is impossible, ways how "noon of emphasis" is added to duplicated verbs and duplicated verbs coming in passive form as well as matter of the letter «ت» being assimilated with nine letter which follow it in the form «"فن

In the third chapter are considered assimilated verbs which are similar to regular verbs in terms of the number of past tense letters and harakats. The assimilated verb is the verb whose first letter is weak. Due to this similarity it is given 
as the third. For instance: the case when number of letters and harakats of the assimilated verb «عَرَّن corresponds to

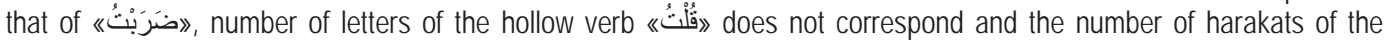
deficient verb "§َ) does not correspond.

The fourth chapter is centered around "hollow verbs" whose middle letter is weak, coming in different verb forms.

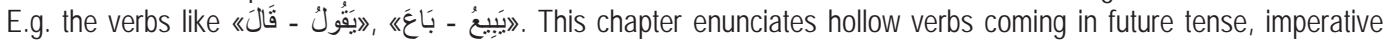
mood and ways how emphatic noon is added to it. Other than that, there was told about formation of "participle" and "past participle" from those verbs and differences in views of the famous linguists as Sibayeuhi and Ahfash regarding dropping of the middle weak letter or the letter "uau" following it from past participle.

In the fifth chapter the deficient verbs were discussed that is the verbs whose last letter «ل» was weak letters. They are called "deficient verbs" because there is a deficiency in harakat of the last letter or the last letter drops in case of jazm. This subject also concerns the conjugation of deficient verbs in future and past tenses and ways of formation of imperative, participle and past participle.

In the sixth chapter highly deficient (lafif verbs) verbs are discussed. Highly deficient verbs are the verbs with two weak letters. Like other scholars Al-Sygnaqi considered "lafif verbs" dividing them into dispersed aggregation (mafruq) and contiguous aggregation (maqrun) groups.

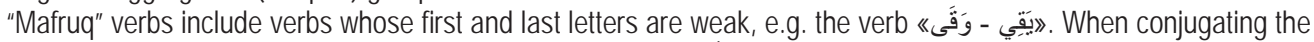

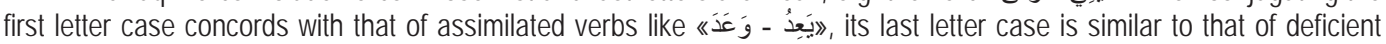

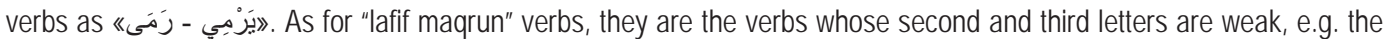
verb "نَطوي - طَوَى" The author said the case of that verb was like that of deficient and hollow verbs. When he enunciated hollow verbs in the fourth chapter, he dwelled upon this type of verb. Apart from it, like in other chapters types of highly deficient verbs and ways of formation were comprehensively studied with examples.

The seventh chapter covers "Mahmuz verbs" (Hamzated verbs) and its types. The verbs is called mahmuz, if the

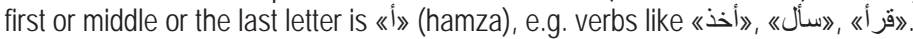

However al-Sygnaqi put forth the following principles dividing verbs whose first letter "ن is hamzated into five groups, verbs whose second letter «ع» is hamzated into three, verbs whose last letter "ل» is hamzated into four groups:

a) Only the first letter «ف) of the "duplicated verb" can be hamzated.

b) Only the second letter «ع» and third letter «ل» of assimilated verbs can be hamzated. For example: verbs like

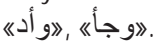

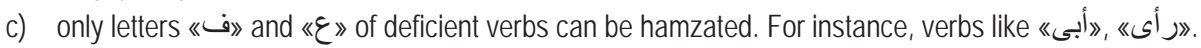

d) Only the letter «ع» of "lafif mafruq" verbs, the letter «ف» of "lafif maqrun" can be hamzated. For example,

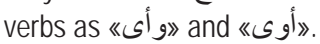

Also, in this chapter were brought into mention such morphological matters like ways of writing Hamza at the beginning, in the middle and at the end of a word as well as its transition and its influence to other letters.

Al-Sygnaqi was the scholar who followed principle of Basra school in linguistics. He brought to notice opinions of both sides by saying "they say like this, we say as follows", thus he insinuated to Kufa school followers when he said "they" and Basra school followers when he said "we". Nonetheless, the scholar did not accept fully some conclusions of Basra representatives concerning certain matters, on the contrary, he put forth his arguments against opinions under his doubt, discussed them and provided proof to his reasoning. Husamuddin having acquired vast scientific, theoretical achievements of Arabic grammar referred to methodology of Basra school and resumed and developed the already solidly established tradition. That is why it is unreasonable to think that reflections in "Al-Najah" are something which stands apart from advanced traditions, experiences of Arabic grammar experts. The fact that al-Sygnaqi when approaching some matters supported views of Kufa school representatives serves as evidence of his freedom from onesided thinking, that he was a scholar with extraordinary conclusion-making feature.

\section{Conclusion}

Investigating spiritual heritage that has been passed down to us through ages and handing it over to generations to come is one of our main duties. This article examines the contribution of Husamuddin al-Sygnaqi, renowned scholar of Turkic world which has been as unavailable as uncultivated land for us until today, to development and dissemination of Islamic culture. Particularly, linguistic features of the scholar's works, matters of Arabic linguistics in them have been mentioned.

The scholars like Husamuddin al-Sygnaqi having been guided by rich lexical-semantic resource of of Arabic language, exerted all their energy to to interprete religious texts and their units and draw appropriate verdicts out of them. Thus, they established the methodology of Islamic law basics having consolidated linguistic and legal principles. 
Al-Sygnaqi not only investigated linguistic topics from grammatical viewpoint in his works related to "Fiqh basics", but also dwelled upon some suobjects which had been unavailable to linguists or uninvestigated by them. He analyzed some subtle linguistic matters which were not covered by grammatical studis and required special researches by applying logical, scientific methods.

Thus, Husamuddin al-Sygnaqi, theologian, legal expert who had been born in Kazakh land gained recognition by deeply probing linguistic matters in his works devoted to Arabic linguistics and Islamic studies.

\section{References}

Ahmad, Nasr (1998). Al-Muassal fi sharh al-Mufassal li Imam Huseyin bin Ali bin Hajjaj as-Sygnaqi. Risalah Doctora (Doctoral dissertation). Saudi Arabia: Umm Al-Qura University

Al-Sygnaqi, Husamuddin. (2003) Al-Uafi. Cairo: Dar al-Qahirah.

Al-Sygnaqi, Husamuddin. (1993-1994) Al-Najah. Risalat magistir. Mecca: Umm Al-Qura University.

Al-Sygnaqi, Husamuddin. (1998) Al-Mufassal. Risalat Doctora. Mecca: Umm Al-Qura University.

Al-Khwarizmi, al-Qasim (1990). Al-Tahmir. Mecca: Umm Al-Qura University

Al-Zabidi, Murtada (1989). Taj al-Arus. Kuwait: Matbagat hukumatu al-Kuwait

Bagdadi, Isma'il Pasha (1951). Hadiyah al-arifiyn. Istanbul. Beirut: Dar Ihya al-Turas al-Arabi.

Barthold, Vasily (1928). Turkestan Down to the Mongol invasion. London: Printed by the oxford university press for the trustees of the "E.

J. W. Gibb Memorial" and published by messrs. Luzac and CO.

Guy Le Strange (1985). Buldan al-Khilafah al-Sharquiah. Beirut: Muassasa al-Risalah (Resalah Publishers)

Haji Khalifa (2008). Kashf al-zunun. Beirut: Dar Al-Kotob Al-Imiyah

Itkani, Amir Katib (1999). Al-Tabyin. Kuwait: Wizarat al-Awqaf wa al-Shuun al-Islamiyah

Kerim, Shamshadin (2012). Siganak sanlagi. Almaty: Nur Mubarak

Lakhnawi, Muhammad Abdul Hay (1998). Al-Fauaid al-bahiyah fi tarajum al-Hanafiyah. Beirut: Dar al-Arqam.

Rahmi Yaran (2009). Signaki. Türkiye Diyanet Vakfı İlâm Ansiklopedisi. C 37. Ankara: TDV.

Suyuti, Jalaluddin 1979: Bughyat al-Wu'ah fi Tabaqat al-Lughawiyn wa al-Nuqah. Beirut: Daru al-Fikr.

Salami, Rafi (2000) Muntahab al-muhtar. Beirut: Al-Dar al-Arabiya lil-mausuah

Qurashi, Abdul Qadir (2005). Al-Jawahir al-mudiyah fi tabaqat al-Hanafiyah. Beirut: Dar Al-Kotob Al-Imiyah.

Usaimyin, Abdur-Rahman (1990): Al-Tahmir. Risalah Doctora (Doctoral dissertation). Mecca: Ummu Al-Qura University. 